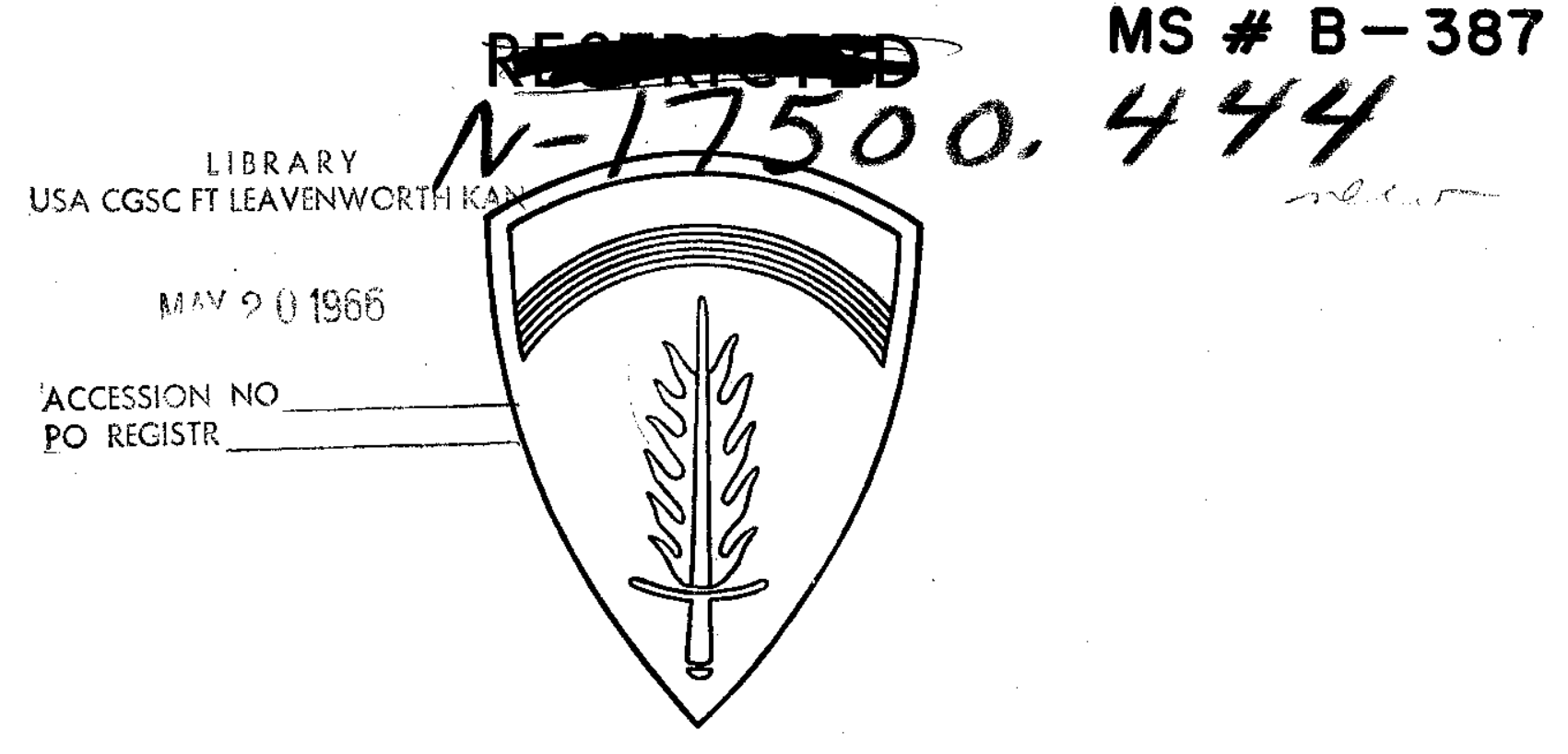

ENGLISH COPY

\title{
THOUGHTS ON WORLD WAR II
}

HISTORICAL DIVISION

HEADQUARTERS UNITED STATES ARMY, EUROPE

FOREIGN MILITARY STUDIES BRANCH

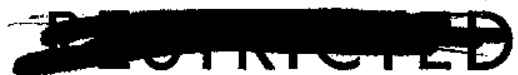




\section{Report Documentation Page}

Form Approved

OMB No. 0704-0188

Public reporting burden for the collection of information is estimated to average 1 hour per response, including the time for reviewing instructions, searching existing data sources, gathering and maintaining the data needed, and completing and reviewing the collection of information. Send comments regarding this burden estimate or any other aspect of this collection of information,

including suggestions for reducing this burden, to Washington Headquarters Services, Directorate for Information Operations and Reports, 1215 Jefferson Davis Highway, Suite 1204, Arlington

VA 22202-4302. Respondents should be aware that notwithstanding any other provision of law, no person shall be subject to a penalty for failing to comply with a collection of information if it

does not display a currently valid OMB control number.

\begin{tabular}{|c|c|}
\hline $\begin{array}{l}\text { 1. REPORT DATE } \\
\mathbf{1 9 4 7}\end{array}$ & $\begin{array}{l}\text { 3. DATES COVERED } \\
\text { - }\end{array}$ \\
\hline \multirow{3}{*}{$\begin{array}{l}\text { 4. TITLE AND SUBTITLE } \\
\text { Thoughts on World War I. }\end{array}$} & 5a. CONTRACT NUMBER \\
\hline & 5b. GRANT NUMBER \\
\hline & 5c. PROGRAM ELEMENT NUMBER \\
\hline \multirow[t]{3}{*}{ 6. AUTHOR(S) } & 5d. PROJECT NUMBER \\
\hline & 5e. TASK NUMBER \\
\hline & 5f. WORK UNIT NUMBER \\
\hline $\begin{array}{l}\text { 7. PERFORMING ORGANIZATION NAME(S) AND ADDRESS(ES) } \\
\text { Department of the Army,Washington,DC,20310 }\end{array}$ & $\begin{array}{l}\text { 8. PERFORMING ORGANIZATION } \\
\text { REPORT NUMBER }\end{array}$ \\
\hline \multirow[t]{2}{*}{ 9. SPONSORING/MONITORING AGENCY NAME(S) AND ADDRESS(ES) } & 10. SPONSOR/MONITOR'S ACRONYM(S) \\
\hline & $\begin{array}{l}\text { 11. SPONSOR/MONITOR'S REPORT } \\
\text { NUMBER(S) }\end{array}$ \\
\hline
\end{tabular}

12. DISTRIBUTION/AVAILABILITY STATEMENT

Approved for public release; distribution unlimited

13. SUPPLEMENTARY NOTES

14. ABSTRACT

An anlysis of World War II as seen from a historic and philosophic point of view.

15. SUBJECT TERMS

16. SECURITY CLASSIFICATION OF:

a. REPORT

unclassified b. ABSTRACT

unclassified c. THIS PAGE unclassified
17. LIMITATION OF ABSTRACT

\begin{tabular}{|c|l|}
\hline $\begin{array}{c}\text { 18. NUMBER } \\
\text { OF PAGES } \\
\mathbf{1 4}\end{array}$ & 19a. NAME OF \\
& \\
&
\end{tabular}





\section{MS $\#-387$}

Thoughts on World War II

by

Quenther Blumentritt, Qenerai aer Infanterie a.D.

Trandlator: Anne Hall

HISTORICAL DTVISION

HFADQUARTERS

DITTED STATTS ART, BDROPE 



\section{The Var of $1939 / 45$, a neen from a \\ blatorte-phtiogophic noint of yiox.}

\section{A. Preliminary Remarke}

A. enntenponerles, we maturally look upon this war as well as the flrst world war only Indirectly world-bhoking evente. He consider theif origin and course from the polltioal and military standpoint. Oar Jutgment is Influeneed by the personel, inner expertences.

One could say that the whole worla is inolined to se such ahooks whioh are still taking effect - "ogotistically" gevery nation seas hex erm point of viow.

The praotical "Realpolitik" has to oonsider these eventualities. The train of thought of prosale politios necsesarily hes to be defferent from that which meditative profemsor and philosophers may bring out In their studies.

1 Wevertheless, it is tempting to look upon and understand suoh great event 1ndenendentir from the prevaling splrit of the times and the nomentar 17y necestary Moalpolitik."

As in knoum eramaxpartabea, universal hiatory proves that great upheavaln of the past are oen dtfemanting in every century, as soon as the feolings of later generations have become detached from paat events. menorles of which have already faded.

Great wars, such at those of $1914 / 18$ or $1939 / 45$, are $11 k$ explestons of moter which in 1tself is already not muning smoothly. 
Bxaotly the sume is the case wth the great war porioti before 1914! Each respective contemporary person 18 , durlng his short iffe, wostly Inolined to see the senses of such oatastrophes, which effect him serlously, in the person of responstble men and responstble governmenta. Howevor, 1ater reclections show in nost oases that these "men", these "governmentg" were only tools, whthout whom the important development world aloo have taken place. Thexefore, we so often find confloting oplnions about great men. Every oentury looks upon the "man" of history With its ow spirit of the times and ramodels this man according to ita an tate. Ho is used as political advartising for thelr own propaganda purposes. Ideas and goals, which they never had in their Iffetine, are often falsely acaribed to great men. Only those episodes in thair 11 fe and only those uttarances are seleoted which sem to serve this purpose. I am clting below a feu of the many exmoles, whereby, of couree, German and Furopean cases predominate:

1. Genohic than, is on the one hard, reprosented at nothing else but the astat10 usurper, coourge of god and incondiary. Then again, he becomes the great atatemen wth ramable talents, a m, at whose nomad"s oourt art and solence flourlshed.

2. Attilan finot considered the terror of purope, - ecconding to Iater desoriptions - seems to have been a wise and cultured "great" wan.

3. Gharles the Great (to whom he belongs is matter of alspute betweon the Gamen and French people) (t condemned because, for the cake 
of religlous belief, he completely rooted out the Saxons. Then again, however, he beowes the great emperor with polltical foresight, who vants to wite the "Franconians" and the "Teutons", and at whose court the arte flourlsh and the way is pared for the Chrietian religion.

4. Constentine the Great was an who, for purely politieal pumpess, made roon for Obristiantity in his emplre. Hoverer, his eneutioe look upon htm az an emperor, whose personal and polftical ations wer arthing but "Christian,"

5. The great experors of the Franconians, the Buxon and the Hohenstaufon are, to this day, atill measured according to two kinds of standards.

6. The great men among the Popes are aonstantiy subject to difference of optinton.

7. Wey 21ght to oonstantly thrown upon the zotions of charles $V_{*}$, Walleneteln, Gustar Bdols, Charles XII., Napoleon, Frederlok the Great, Biamarck, oto., and they and many other mon are constantly afther being oondewned or pratied to the sittes.

And yot, all these are only exponent of thotr time:

If Napoloon I. had been born 50 years earlfer or later than was atually the oase, he would have remalned anentity: He had to be born at the the of social and aplritual revolution in prance, in oxder to fulfill the misulon with which the wad ontrusted him. No man, who it oulled "great" today, would have become "groat", if he

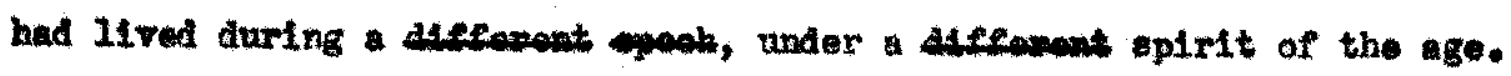




\section{B. Chanren}

There were more really "great" statesmen Aurlng former time then there are today, Let us just take the last fow oenturles! Thore we had Richellex, Mosarin, Floury, Gambetta, Clemenowa, or the Pltte, Palmeratone, Disraell, te ", or Goorge Washington, Livioaln, oto. or Notternith or the Conte de Cavaur, or Btemarck.

In wo way or other, every nation adnires the ominence and foresight of these great statesmen.

that is the reason for this? People of coday have the pame qualtties and poriap grenter knowledge! But they are more bound by the evolution of nations Into parliamentaxy oomuntt1es. They have to take a thouband things tnto consideration and cannot always do that which reason has advised them to do long since. Statemen of today are more dependent on the refinot oconomie system, on publie opinton. Wth all the progresa in the West, thil development earliy leads to the "masses", whereby the Individual can no longer bring out his qualtition freely as he did prevlously.

Only the Dast, with the innor struture of 1 to autoeratio reglme is more Independent in this. "Publis opinton" is not valued too highly In the Fast and is also forelgn to the ahmacter of the Fanterner. For thet he 1 to too mob the product of the collective systes and not an Individual.

The 29th and 20th century aro peflods of great ohanges and 
processen of formentation. They are phenorene in the realn of world view, world conony and the social and religious flald. Wo are in the midet of this opiritual and matertel controversy, without being atre of it during our short 11fetime. Hars not only temible, disastrous periods, whloh are the fault of indiriduals only; they are also thunderatroke antdst the rumbling of latent storm.

One should think during our century of progress in every realm that todar, there covit no longer be any "Ideologtcal" probleme, for the solution of whlch wars would be fought. It was belleved that the religtone wars of the 16 th and 17 th oentury and the epirituel revolution in Franes at the turn of the 18th century would be the last wars.

This is net the case: Democracy, bolshevlim, national sociallem and faccism ore reapeotively, were ideologlos whtoh cannot be dented and wioh have resulted in great controverales. The last two vere in wost of their goalo imposelble in a mororn, progresstve world. Their destruotive power even moceeded in equting s epell on sueh edueated and bastosily good-naturad people as the Gomman people. Howerer, communtar contlmes. Although 1ts outer forms may oonform to western oonosptions, this change may be of atrategle nature. Escentially, it

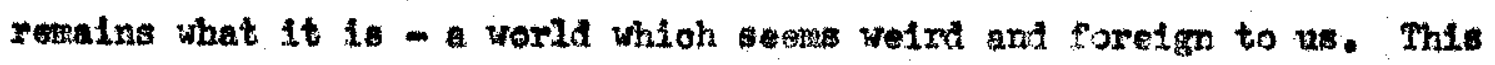
the Gorman pople and the Qmman Wehmoht of yenterday also felt and therefore desperately fought to the polnt of velf-eacriftee. Todey: too, after complote oollapse and utter elfaination, the Gorman poople during the frev lections in the three weatern zones - with thel. 
votes dewonstrated thetr rejeation of this world which te fareign to us. A a western nation, we would heve deservol a bettex polltical leadership than that of Insasi,ty. Now st is over - but I believe that our phllosophy mall remeln opsosed to that of the estern worla. However, "1agology" is an important part of the protions, the foelings of a people, 1, o. of publlo opinton, which every stateman has to constder.

From actalletio polnt of view, the ldeas of the Frenoh revalution are atill ative. However, the revalutionery sootaltam has in the West dereloped into the eroluttongry sodalism which afftrme the state and

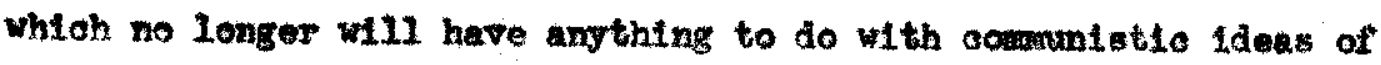
bolsherlatio orlgtn. In 1222 , the Germon people still pought an inner confllet regarding this - todse, this has been overeone, for the soolaliom of our able working masess is postitive oondractive.

In the East, laborers and farmers (kolkhoz - (transls collective farmo f are also moinlined, but nobody will want to asoert that this

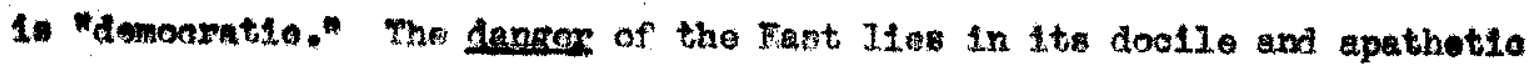
wansess, whioh nre onaly led and have to be used as whole in overy renpeot, in pease well nar. wroe speech, trade unions and strikes are unknows to these. They voxk - roluntarily or not - often ton hours Instead of olght, and they work sheanly. Mhls is signtfloant, for thts

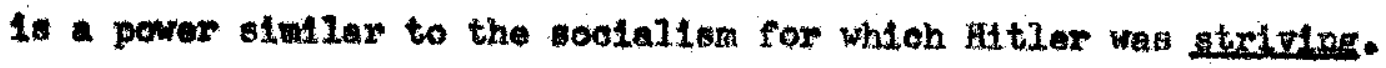
Snolologleal and soctel changer go hand in hand. Old privileger are abolithod, "olasses" are transfomed and now higher levele are doreloped. 
In the religlous fleld too, deviations mat develop there is no longer any room for ald and antiquated disoriningtione, the world has besowe too open and too progresalve for that. Hndertending leaders of churehes and relldlou organd zhtions shall have to watoh thewe developments, In orter to be able to secure true vorld religion of tolerance.

From a silture point of view, war remalns en evil and last revort of all centble politics. We too is being revolutionized. The effect of the new known vaspone of war, the further development of the a1F foree, rooket boubs, eto., extends to the for ancuers of the earth. Great vorld powere regulre the warld-map, the globe for their consideratlons, which are no longer "operational" wat parely etraterde. They oan no longer protect thengelves through tactioal strong polint: a fe: k110meters in area, but reguire wile ond deep outpost areas, which then comprise thotr phere of interect. Thus, the vorid has beoom suall, but the mater meane of destraction have asured largo proportions. Thereforv, only the world-atlas ean be the answer for strategle worid questions, Europe, Arrica, ete. have become merely operationel parta of the wole.

Therefore, on this earth, it is no longer posstble for many, but only very fow exeat men to rule! overything olse has to cilust itcelf one vay or enothex.

There is also anotker fort of var, ythont gune, tanks and atrplanes. It is the "var" of infiltration, egitation and rindermining of pooplo 
minds! Hexe, "offenstre war" Is not yet deflned, because the "orflelal" statemen do not, considar themsalves responetble. Fovever, the actual evente in the world show what the real atm 1s. The Eat excels in this axt:

However, the change in the fleld of yorld eaonomies remains the most infortant. Fvergnan waxts to get on vell! Ile denands of hita statesuan to to it Economica have always bear the bate of all politiss, but in the 20th oentury, it involves the very exdetence of the great powers.

The culture and ofvilizatson of nar destern world is exacting,

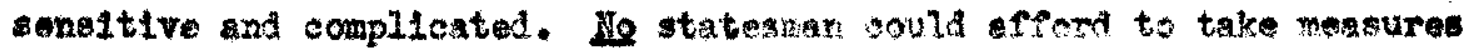
Which would bring about economic decline. Outurally, howerer, ho has

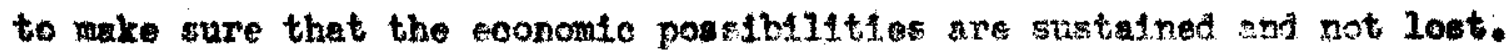
For if this were the asse with a modern vestern nation, it waid aefinitely disintegrate. The more ste in industrialized, the more extenefve 1s Its econony, the less "competits on" oar be tolerated. The earth bas become too stall. to allow many to be on Iirst place. Whenever two large bustness coneerne are ide by tide, there ar only two postibilitien they unite or Ilght each other.

The kreat outlet markte have hecome scenes or destroyed, or aro disputed: However, world poisers wein than in orier to dispoes of their Bocxis.

The clvilization snd oulture of the sestem world is not exacting and is not as complisated. It: people are infenst.tive and thetr nerves 
can stand meh which is unbearable for us. The Fat too porsesses tramendous pace and neture] resotroes, a11 of which have not yet been whoovered by rax. Iechploally, it in also only in the process of conatruetion. For thet, It avali stgelf of trained worker from its own ronks and - stodon knowlodge and breinwork of abduated Cermans. Eolwhoviem has the nater to ungarth the Iatent treasures through alave 1abor. These dangers of sconomio competition in tureala do not as yt oxtst, but these will follow only after $10-20$ yoars of constmation of thls tremendous mehlne. One sould 11ke to hope and say "VIdeant consules!" (trannl, Look ahead, statosmen!)

Wegtern Furone to only heap of mins on the sontinent: Only

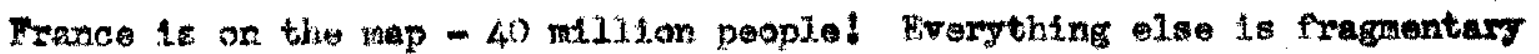
and ??? Fothing but mall, weak, sore points and places, "minor states", sindlar to tho Nurope nap in Germany a hundred yoars ago! Thus, small Westem Burope remalns weak, winerable front, a sensitive spot on the world map.

Here, atd for all to posstble only if these weak formation becme subordinated to great stmuture of the remalning world sea pouers, wllingly jotning ame and allowing themselver to be led. This concemi the mutus laterest of 11 and represents 11 fempreserving Healpolitik" and politice based on recon Which the anall people mast adopt if they do not want to heve to face dangers, whloh, for the mpenent, may be bantehed ly polstlos, but whiok covld, some day, be revived. Thorefore, Wetern furope necä hest-Ruropean oduction. This hat 
to begin with the olear purpose, and the foundation to then strengthened

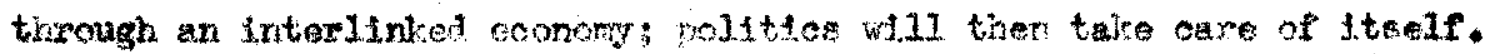
Europe las become old. It hes furfilled a greet maston and now hes to joln forcen.

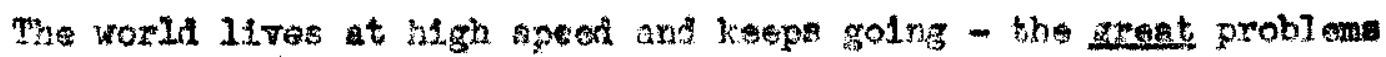
atill hatro not yot been setitid and solved.

Our elviluatlen, hosever, will continue only if it collaborates wh, the the great western world. The romaining frameots of the continent sanpet exist for lons alone and by themenlves. This esilg for a doterning changet to thioking.

There?ore, thinking th terce of a seal of $1: 1000,000$, I soe the catastrophe of the second world war orly as an explosion in the mist of a continuing avolution in ell realna of homen life.

War historie and willtary rofleattons of the soldser are defintely inportant for satre, bot they are not the essentiel thing. That rould be

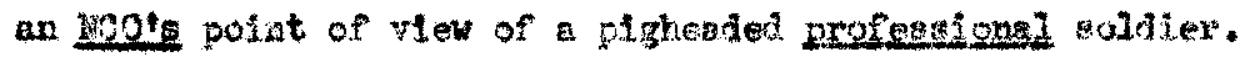

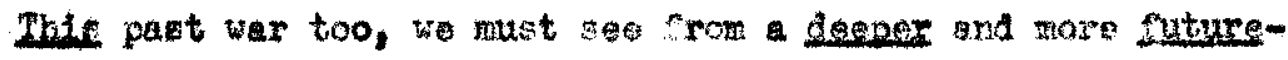
minded polnt of riev! only then can one l.morn th provent worge - or to reoomize it. To this extent, historlo-philosophie reflections on the of 1939/45, an ween frox a hither theld of viston, can only be usetul for all pirtice anoemed. 